\title{
Q-METHODOLOGY STUDY OF STUDENTS BEHAVIOUR DURING PROJECT-BASED LEARNING
}

\author{
BADANIA ZACHOWAŃ STUDENTÓW PODCZAS UCZENIA OPARTEGO \\ NA PROJEKCIE ZA POMOCĄ Q-METODOLOGII
}

\begin{abstract}
The contribution describes the circumstances of the implementation of a chemistry project with the main theme "Chemical show - Harry Potter". Project-based learning belongs between the complex teaching methods, where the desired effect can be influenced by many factors, eg student's attitude, student's overall opinion and feelings about the method. The motivation of the researchers was to understand and evaluate the factors present in the realised project. The analysed factors and behavioural schemes can provide a good starting point for the teachers at planning their projects. With the aim to understand the students' reaction the researchers used Q-methodology to identify the different behavioural groups of participating students based on their real opinion. In the presented research the researchers analyse the response of totally 26 students. As a result totally 6 behavioural examples are presented that teachers can meet during implementation of project based learning. The presented categorization collaborates with other formerly publicised types of student's behaviour, eg students of "pleasant surprises" and "disappointing surprises". However, other additional types of behavioural types emerged $e g$ students orienting and concentrating on the theoretical knowledge, students with very strong need for leading and students with the need of several assessment systems. The presented results can provide a wider view for the teachers in preparing and forecasting the flow of their projects and can help them to prepare the project.
\end{abstract}

Keywords: project-based learning, Q-methodology, student's opinion

From the birth of the idea of project-based learning the method itself became widespread amongst teacher from various education levels. With the student focused view of the project-based learning the method is often implemented in different subjects to provide the students the opportunity to connect theoretical knowledge with the real world through numerous hands-on experiences.

\section{Problem of research}

As long as implementation of any teaching method also the project-based learning can represent various difficulties for the teachers. In the evaluation phase of every project the effectiveness is analysed. The local researches usually concentrate on mapping the ways of the implementation $[1,2]$. Usually in these researches the effectiveness is measured through

\footnotetext{
${ }^{1}$ Department of Didactics and Pedagogics of Chemistry, Faculty of Natural Science, Comenius University, Bratislava 842 15, Mlynská dolina, SK, email: proksa@fns.uniba.sk

*Corresponding author: gabriella.nemeth08@gmail.com
} 
the student's academic results. On the other hand the available results of research from the world are searching the source or more correctly the differences among the effectiveness of implemented projects. Based on some research the impact of the implemented project can vary and can be greatly influenced by the individual difference of the participating students $[3,4]$. Usually the researchers reached to a conclusion, where they differentiated 2 types of students $e g$ students of "pleasant surprises" (students poorly performing during normal classes and performing well during project-based learning) and "disappointing surprises" (students performing well on normal classes and giving poor performance during project-based learning) [3], students "challenge seekers" (students with higher tolerance for failure) and "challenge avoiders" (students with lower tolerance of failure), students of "high-ability" (students more frequently participating in social behaviours and engaging in critical thinking) and "low-ability" (students more frequently participating in social behaviours and engaging in critical thinking) [4]. Based on another researches is generally accepted, that project-based learning method is especially effective in case of disengaged and unmotivated students [4]. Other researches has shown, that the project-based learning can be effective in case of students with learning difficulties as long as by the help of the project based-learning they are able to engage in the learning process at their own level and reach their academic and social goals [5]. According to the worldwide practise the researchers decided to conduct a research, where they concentrate on researching the effectiveness of the project-based learning through other factors than academic results, eg behavioural change and student's opinion.

The results of the above mentioned researches can have a significant impact on the preparation and implementation of any project. Understanding the different type of the students and they expected behaviour during the project can provide the teachers an effective helping tool to plan and implement projects where the effect of the method can be maximised.

\section{Research focus}

The purpose of this study is to find out the students behavioural types during the implemented project in a general classroom with the potential of participation of gifted as long as non-gifted students and students with lower academic performance.

Based on the student's behaviour compared with their results the researchers assess the impact and effectiveness of the implemented project on different student's learning types. The object of the research is implementation of project-based learning primarily on the field of chemistry and identifying the different student's behaviour.

\section{General background of research}

The present study is part of a larger study where totally participated 7 classes of various school in Slovakia. The list of the participating schools is characterized in the Table 1.

All of the classes participated in different projects with the main study field in chemistry. In this study is described the end result of a single class, where students choose to participate and execute a chemical-show. The main aim of the show was to create an intriguing demonstration of different effective chemical experiments, incorporate these experiments in a chosen theme, and create a complex story based on musical adaptation. The whole project was executed during the whole school year (from Project launch taking place in the middle of September to the Project evaluation placed in the middle of June). 
Description of the implemented projects

\begin{tabular}{|c|c|c|c|c|c|c|}
\hline School & $\begin{array}{c}\text { City of the } \\
\text { school }\end{array}$ & $\begin{array}{c}\text { Age } \\
\text { of } \\
\text { students }\end{array}$ & Project theme & $\begin{array}{c}\text { Past } \\
\text { experiences } \\
\text { with projects }\end{array}$ & $\begin{array}{c}\text { Total } \\
\text { number } \\
\text { of groups }\end{array}$ & $\begin{array}{c}\text { Number } \\
\text { of students } \\
\text { in groups }\end{array}$ \\
\hline $\begin{array}{c}\text { 7. year of a high schools } \\
\text { with 8 year duration }\end{array}$ & Bratislava & 17 & Obesity & Limited & 6 & 3 \\
\hline $\begin{array}{c}\text { 2. year of a high schools } \\
\text { with 4 year duration }\end{array}$ & Bratislava & $15-16$ & Carbon dioxide & No & $\begin{array}{c}12 \text { (in two } \\
\text { parallel } \\
\text { classes) }\end{array}$ & $3-4$ \\
\hline $\begin{array}{c}\text { 6. year of a high schools } \\
\text { with 8 year duration }\end{array}$ & Bratislava & $15-16$ & Water & Limited & $\begin{array}{c}12 \text { (in two } \\
\text { parallel } \\
\text { classes) }\end{array}$ & $4-6$ \\
\hline $\begin{array}{c}\text { 2. year of a high schools } \\
\text { with 4 year duration }\end{array}$ & $\begin{array}{c}\text { Dunajska } \\
\text { Streda }\end{array}$ & $\mathbf{1 5 - 1 6}$ & $\begin{array}{c}\text { Chemical } \\
\text { Show } \mathbf{H a r r y} \\
\text { Potter }\end{array}$ & No & $\mathbf{4}$ & $\mathbf{5 - 1 0}$ \\
\hline
\end{tabular}

\section{Sample of research}

26 of the students of the $2^{\text {nd }}$ grade (student's age was between 16 and 17 years) of High-School participated in the project. In the project participated the whole class of a High-School situated in a smaller-town of the south region of the Slovak Republic. The school itself is a relatively newly opened school (the school was established 6 years ago). In the town the school represents an adequate alternative for the students, who want to study in a school with the potential of newer and not only traditional teaching methods. The teaching staff mostly consists of young and enthusiastic teachers. The school is relatively small. Today they have one teacher for every subject.

The most intensively participating teacher from the staff was the chemistry teacher. She is a very passionate and self-motivated teacher with 5-10 year of practical experience in chemistry teaching. She is also a very creative person, who is able to find the opportunity to use any tools for motivating the students and help them to understand chemistry.

The class participating in the project is generally viewed as a class with good academic performance. Amongst the participating students are talented one (with a high achievement level - mostly participating in different chemical and physical competitions - totally 2 students) as long as low-performing students with very low or no motivation to engage in any school activities ( 2 students). The students and the teacher had very limited experiences with implementing projects or participating in project-based learning.

\section{Instrument and procedures}

The project evaluated in the research was implemented during the school year from September 2012 and June 2013. Because the teacher itself had very limited experiences with implementing project-based learning into teaching the preparation and the implementation was executed in the following steps:

1. Preparation phase: The preparation mostly entailed several meetings with the participating teacher, where the main characteristics of the project were decided eg main theme (alternative themes), thematic definition of the groups, timetable, preparation and selection of helping and controlling tools for the students and preparation of the various abnormalities or unplanned scenarios. 
2. Project launch: During the project launch the students met the final idea of the project. Based on the student's interest they were divided into groups (finally to 4 groups: chemical experts - responsible for the experiments (11 students), technical experts responsible for the audio and visual effects (7 students), media experts - responsible for posters and commercials (6 students), experts of curiosity - responsible for finding and implementing curiosities into the project (6 students)). At the project launch the groups wrote a group contract of expected behaviour during the project. They also get their first tool whit a list of literature where they could begin their theoretical research.

3. Project planning and preparation of the big day: After 2-3 week long period of theoretical research the students begun with their plans and initial preparation of the end performance based on their group's aims. For the planning they used planning forms, where they could state their main aims and divide them into smaller parts [6]. During the preparation they also wrote work diaries [7].

4. The big day: At the end the whole chemical show was presented in front of the school (teachers and students). The performance consisted of 3 main parts:

a. Short presentations of interesting facts about the used chemicals and how the show was put together.

b. Funny description of the actors acting in different roles during the performance.

c. Performing of the show itself.

5. Project evaluation: The following lessons after the performance were dedicated to student's assessment. Based on the general practise in assessing of project-based learning the implemented assessment system was divided into 2 main fields:

a. Self- and peer-assessment of student's performance in the groups and written assessment of the project by the help of a questionnaire [8-11].

b. Project assessment with the use of Q-methodology (Q-methodology) a qualitative searching method, where the subjectivity of the researchers may have impact on the data interpretation the researchers present their interpretation of the data in combination with their knowledge and experiences about the students [12-17].

\section{Data analysis of the Q-methodology}

The students were presented with totally 58 statements (Q-sets). The Q-sets were collected primarily from the student's statements noted during the implementation and realization of the projects in all of the classes ( 7 classes, totally 120 students) participating in the research. The sets were collected from various student-teachers, student-student verbal interaction mostly during the consultation. During the process of selection of the statements the researchers focused on statements providing criticism of the provided helping tools, providing opinion about the steps and workflow of the implemented project, statements describing student's interaction in a group and generally statements about group work. The collected statements were further enriched by adding statements about the assessment system (statements considered as important in gaining more complex knowledge about the effectiveness of the project and the assessment system). As the last step publication and mass-media based statements were added. The final set of Q-sets was divided into five thematically different groups:

a) Statements describing group work

b) Statements describing the gained knowledge and experiences

c) Overall opinion about the implemented project 
d) Statements describing the role of teacher in the implemented project

e) Statements describing the implemented assessment system

Each statement was printed on a numbered card, which was randomly arranged in an envelope.

The cards were arranged in a 58-celled quasi-normal distributed scale, which ranged from -5 to +5 . On the scale +5 represent absolute agreement with the statement and -5 represent the absolute disagreement with the statement. The final scale with quasi-normal distribution of the Q-sets is shown in Table 2.

Scale with quasi-normal distribution of the Q-sets

Table 2

\begin{tabular}{|c|c|c|c|c|c|c|c|c|c|c|c|}
\hline Scale & $\mathbf{- 5}$ & $\mathbf{- 4}$ & $\mathbf{- 3}$ & $\mathbf{- 2}$ & $\mathbf{- 1}$ & $\mathbf{0}$ & $\mathbf{1}$ & $\mathbf{2}$ & $\mathbf{3}$ & $\mathbf{4}$ & $\mathbf{5}$ \\
\hline $\begin{array}{c}\text { Max. number of } \\
\text { statements }\end{array}$ & 3 & 4 & 5 & 6 & 7 & 8 & 7 & 6 & 5 & 4 & 3 \\
\hline
\end{tabular}

As long as Q-methodology requires only a limited number of respondents [15] totally 26 of the students participating in the research distributed the Q-sets. For analysis of the data program package were used from PCQ soft (PCQ Analysis Software for Q-Technique). After digitally editing every sort in the program the researchers choose the recommended approach for extracting the factors. Based on that a Varimax rotation was adopted and in the result only those factors were involved, which had $\geq 0.45$ eigenvalues.

\section{Results of research}

With the above described method totally 6 factors emerged. Table 3 summarizes the emerged factors which are separately analysed.

Table 3

Summarisation of emerged factors

\begin{tabular}{|c|c|c|c|}
\hline $\begin{array}{l}\text { Factor and label } \\
\text { of the factor }\end{array}$ & $\begin{array}{c}\text { Number } \\
\text { of respondents } \\
\text { loading } \\
\text { on the factor } \\
\end{array}$ & $\begin{array}{l}\text { Most significant statements loading } \\
\text { on the factor }\end{array}$ & $\begin{array}{c}\text { Location of the } \\
\text { statement on } \\
\text { the score sheet }\end{array}$ \\
\hline $\begin{array}{l}\text { A } \quad \text { - Project-based } \\
\text { learning is a motivating } \\
\text { method for creativity }\end{array}$ & 2 & $\begin{array}{l}\text { Project provides opportunity to realise your own } \\
\text { creative ideas. } \\
\text { Planning and recording our plans and progress } \\
\text { has no use and it is enough to provide an update } \\
\text { verbally. }\end{array}$ & $\begin{array}{l}-3 \\
+5\end{array}$ \\
\hline $\begin{array}{l}\text { B - I know what is } \\
\text { important for me, } \\
\text { I always reach my goals } \\
\text { and I work alone }\end{array}$ & 2 & $\begin{array}{l}\text { Teacher's help during the project is not necessary. } \\
\text { By the help of project we learn skills and } \\
\text { information useful in our future. } \\
\text { During the project I learnt to present more } \\
\text { creatively, because among others I had to focus } \\
\text { on eye-contact, speech and demonstrating our } \\
\text { products. }\end{array}$ & $\begin{array}{l}+1 \\
-5 \\
-4\end{array}$ \\
\hline
\end{tabular}




\begin{tabular}{|c|c|c|c|}
\hline $\begin{array}{l}\text { Factor and label } \\
\text { of the factor }\end{array}$ & $\begin{array}{c}\text { Number } \\
\text { of respondents } \\
\text { loading } \\
\text { on the factor }\end{array}$ & $\begin{array}{l}\text { Most significant statements loading } \\
\text { on the factor }\end{array}$ & $\begin{array}{l}\text { Location of the } \\
\text { statement on } \\
\text { the score sheet }\end{array}$ \\
\hline $\begin{array}{l}\mathrm{C}-\mathrm{I} \text { am the leader or } \\
\text { there is no teamwork }\end{array}$ & 3 & $\begin{array}{l}\text { Ideal project would be realised as a project-week, } \\
\text { where students would have the opportunity to } \\
\text { fully concentrate on the project. } \\
\text { It is good to work without the teacher's exact } \\
\text { instruction. } \\
\text { Chemical reactions are the most important part of } \\
\text { every chemical project. }\end{array}$ & $\begin{array}{l}-5 \\
-2\end{array}$ \\
\hline $\begin{array}{l}\text { E Project is an } \\
\text { opportunity where I can } \\
\text { develop my knowledge } \\
\text { and personal skills }\end{array}$ & 3 & $\begin{array}{l}\text { The difference between project-based learning } \\
\text { and other teaching method is that during the } \\
\text { project we do not have to study/learn. }\end{array}$ & -4 \\
\hline $\begin{array}{l}\text { F - The project provides } \\
\text { opportunity to develop } \\
\text { my skills, but the most } \\
\text { important for me is } \\
\text { theoretical knowledge }\end{array}$ & 3 & $\begin{array}{l}\text { I learnt less information during the project as on } \\
\text { other lessons. } \\
\text { It is really hard to choose correct literature for } \\
\text { your presentation. } \\
\text { Creating products is the funniest part of the } \\
\text { project. } \\
\text { Planning and systematic work is not needed in } \\
\text { a project either way the most important thing is } \\
\text { the end result. } \\
\text { I prefer to have lessons with more traditional } \\
\text { teaching methods, than with project. }\end{array}$ & $\begin{array}{l}+5 \\
+2 \\
-3 \\
-1 \\
+5 \\
+5\end{array}$ \\
\hline $\begin{array}{l}\text { I - The project needs } \\
\text { several assessing method } \\
\text { at every steps }\end{array}$ & 1 & $\begin{array}{l}\text { A traditional (by the help of MS Office } \\
\text { Power-Point or Poster) presentation of facts is } \\
\text { a sufficient goal and product of a project. } \\
\text { There is no need for any tools from teachers to } \\
\text { realise the project. } \\
\text { The best is when teachers assess the student's } \\
\text { work just verbally. } \\
\text { Difference between normal lessons and lessons of } \\
\text { the project is that during the project we made } \\
\text { a model and worked in groups. }\end{array}$ & $\begin{array}{l}+3 \\
-5 \\
+4\end{array}$ \\
\hline
\end{tabular}

\section{Factor A - Project-based learning is a motivating method for creativity}

Students loading on the factor are creative students, who eagerly engage in creative activities, as drawing, photographing, etc. Based on their significantly loading statements the students were not able to realise their own creative ideas during the project, however according to their other statements on extreme locations (location on \pm 3 to 5 on the score sheet) they were able to find creative activities during execution of other team member's ideas. To enable effective group work they rather choose to collaborate and go with the flow 
of the majority of the group. That also means that for the mentioned students is more important to have fun and excitement during the realisation of a project, than their individual expectation. For that statement we also can find proof in the second significantly loading statement.

\section{Factor B - I know what is important for me, I always reach my goals and I work alone}

Students loading on the factor are generally viewed as well performing students on normal lessons. Based on their interaction during the project and location of significant statements they emerged as "disappointing - surprises". For these students expanding their own theoretical knowledge is the most important. Generally they were not able and willing to work creatively or with the other group members. The students viewed their classmates as a faint company who could only decrease the high quality work which they would do alone. It is understandable, that these kinds of students are used to work alone, without any help of their classmates or teachers. They know that they are well performing under the circumstances of the traditional school, what they already understand. Because of that they would not want to change the rules where their success could be risked.

\section{Factor C - I am the leader or there is no teamwork}

Students loading on the factor based on their interaction with their group members and teachers are assessed as evident leaders. Based on their significantly loading statements they expect the teacher's coaching and instruction, but most importantly the teacher's validation of their position as leader. Evidently in their groups they were not able to strongly establish their position by themselves and that meant for them to not collaborate/collaborate as little as possible in the project's activities. They also criticise the project's timetable which also proves their effort to find reasons for their lack of cooperation and their not best quality performance.

\section{Factor E - Project is an opportunity where I can develop my knowledge and personal skills}

Students loading on the factor generally are assessed as well-performing students; however they do not belong between students with evident management and leadership skills. They understand the project as something more than traditional lessons, where is an opportunity to learn and experience real life problems.

\section{Factor F - The project provides opportunity to develop my skills, but the most important for me is theoretical knowledge}

Students loading on the factor are also recognised as well-performing students on traditional lessons. However in comparison with the students from the previous group they had more conservative understatement of their development. Based on their analysis the researchers identified a group of students whom theoretical knowledge is extremely important, but as a difference from the students in factor B are more socially sensible. The students were comfortable during traditional lessons, but were more open-minded to work with the group. Not because of the lack of trying, but they failed to favour the project. For them project meant extreme bending off from the traditional lessons, where they can use their theoretical knowledge in a well-known environment. 


\section{Factor I - The project needs several assessing method at every steps}

Student loading on the factor has a personality trait of a maximalist. For the student project provided an opportunity to work creatively and by other method during the lessons, but also meant for her a risk of her grade/performance. She knew well how to gain the best grade and appreciation on the traditional lessons. While in comparison with the traditional lessons the project-based method represents a less understood method.

\section{Discussion}

The results of some researchers $[3,5]$ studying the impact of the project-based learning very often divided the students into 2 categories. The recent study shows a wider categorisation of the students.

Based on the recent study the researchers identified several groups of students' behaviour enriched by the student's personality traits. According to the analysis of above mentioned factors the researchers defined the following statements.

- Students with the will to cooperate can find the fun and positive side of the project (students of factor A, E, F and I). It is a good example why teachers should often change the teaching methods during the lessons, because that way the students may get used to the changing circumstances and may react for the changed circumstances of the project more open-mindedly.

- Students who have an expense need for theoretical knowledge can react differently for the project-based learning:

- Well-performing students with certain level of arrogance would try to decline group work (students of factor B).

- Socially more sensible well-performing students, who often avoid arguing and conflicts can involve in the project, but there is a risk, that will view the project as an activity providing fun and excitement, but not sufficient way for education (students of factor F).

o Well-performing students who well knows the grading rules in the traditional system can view the project as a risk for their good performance (students of factors B and I).

○ Well-performing students with open-minded personality trait, for whom the factual knowledge is not essential can find the positives in the project-based learning (students of factor E).

The authors recommend in avoiding the criticism of well-performing students to provide in the above mentioned examples more opportunity to learn and study facts for the individuals with that kind of need (eg naming in the group the responsible for the theoretical background, who will have the prior responsibility to provide enough knowledge for any activities).

- $\quad$ Students with very strong management and leadership personality traits would naturally react as a team leader, while several problems (eg refusing further cooperation) could arose when they are not accepted as leaders (students of factor $\mathrm{C}$ ). As the authors point of view manager skills can be beneficial from the point of group work and to avoid the mentioned problem it would be beneficial to establish the groups based on the teacher's best knowledge. 


\section{Conclusions}

According to the above described research the students participating in the project divided into 6 factors. Summarising the results described in the discussion the students who are able to cooperate eagerly, can view the project as a positive experience to improve their creativity. Also students generally viewed as well performing ones many times have higher expectation on the project mostly on gaining the same amount of theoretical knowledge as they are used to on the other classes.

The above described research showed that every student in a class where a project is implemented can react differently, hence one of the main roles of the teachers who act as a consultant to prepare how to treat the students to perform according to their best ability. For that reason this article presents some behavioural examples from real life implemented project, where several groups were identified.

\section{References}

[1] Kalafutová J, Ganajová M. Využívanie projektovej metódy vo výučbe chémie v Košickom a Prešovskom kraji (The use of project-based learning in teaching chemistry in region Košice). In: Metodologické otázky výzkumu v didaktice chemie (Methodological questions in research of didactics of chemistry). Hradec Králové: Gaudeamus; 2009.

[2] Ganajová M, Kalafutová J, Siváková M. Projektové vyučovanie v chémii: Didaktická príručka pre učitel’ov základných škôl (Project based learning in teaching chemistry: Handbook of didactics for elementary schools). Bratislava: ŠPU Rempo s.r.o.; 2010.

[3] Rosenfeld M, Rosenfeld S. Understanding the „surprises” in PBL: An exploration into the learning styles of teachers and their students. European Association for Research in Learning and Instruction (EARLI). Göteborg: University of Göteborg; 1999. Retrieved 05.03.2012 from http://www.designworlds.com/ techscape/Sherm_LStyles.html.

[4] Thomas J. A review of research on project-based learning. San Rafael: The Autodesk Foundation, 2000. Retrieved 12.20.2011 from http://www.bobpearlman.org/BestPractices/PBL_Research.pdf.

[5] Filippatou D, Kaldi S. The effectiveness of project-based learning on pupils with learning difficulties regarding academic performance, group work and motivation. Internat J Special Education. 2010;25:17-26. Retrieved 10.10.2015 from http://www.internationaljournalofspecialeducation.com/articles.cfm? $\mathrm{y}=2010 \& \mathrm{v}=25 \& \mathrm{n}=1$.

[6] BIE 1 (Buck Institute for Education 2012). Tools. Online tools. Retrieved 11.01.2012 from http://www.bie.org/tools/freebies.

[7] Németh G. The use of work diaries during project-based learning in chemistry. In: Projektové vyučování v př́rodovědných předmětech. Praha: Department of Pedagogics Charles University; 2014.

[8] BIE 2 (Buck Institute for Education 2012). What is PBL? Online guide for PBL. Retrieved 11.01.2012 from http://www.bie.org/about/what_is_pbl.

[9] Bidwell SE. Project - based Learning for Cosmetology Students. Ohio: Publications, Center of Education and Training for Employment. 2000. Retrieved 12.12.2015 from: http://eric.ed.gov/?id=ED448282.

[10] Butler SM, McMunn ND. How to assess student performance in science: Using classroom assessment to enhance learning. Greensboro: SERVE Center at the University of North Carolina at Greensboro, Institute of Education Sciences U.S. Department of Education; 2005. Retrieved 12.12.2015 from http://eric.ed.gov/?id=ED498182.

[11] Németh G, Prokša M, Šafránková Z. Project-based learning in chemistry for students in the second year class of a high school with 8 year duration and with students self-assessment. Biológia, Ekológia, Chémia. 2013;1:2-10. Retrieved 21.12.2015 from http://bech.truni.sk/index.php?option=com_content\&view= category\&layout=blog\&id=53\&Itemid=78\&lang=sk.

[12] Bianchi G, Popper M, Lukšík I, Supeková, M. Q-metodológia: Alternatívny spôsob skúmania sexuálneho zdravia (Q-methodology: An alternative approach of researching sexual health). Bratislava: Slovak Academy of Sciences; 1999. 
[13] Stenner P, Popper M, Lukšík I, Supeková, Pujol J. Constructions of sexual relationships. A study of the views of young people in Catalunia, England and Slovakia and their health implications. J Health Psychol. 2006;11:669-684. DOI: 10.1177/1359105306066617.

[14] Van Excel J, De Graaf G. Q-methodology: A sneak preview. 2005. Retrieved 15.11.2014 from http://qmethod.org/articles/vanExel.pdf.

[15] Yang Y, Montgomery D. Gaps or bridges of multicultural teacher education: A Q study of attitudes toward student diversity. Teaching Teacher Educat. 2013;30:27-37.

[16] Øverland K, Thorsen AA, Storksen I. The beliefs of teacher and day-care staff regarding children of divorce: A Q methodological study. Teaching Teacher Educat. 2012;28:312-323.

[17] Žoldošová K, Prokop P. Causal attribution of school success investigated by Q-methodology. Paidagogos; 2005; 2. Retrieved 31.05.2014 from http://www.paidagogos.net/issues/2005/2/1/article.html

\title{
BADANIA ZACHOWAŃ STUDENTÓW PODCZAS UCZENIA OPARTEGO NA PROJEKCIE ZA POMOCA Q-METODOLOGII
}

\begin{abstract}
Abstrakt: Opisano realizację projektu z chemii, którego głównym tematem były „Chemiczne pokazy - Harry Potter". Uczenie się oparte na projekcie należy do skomplikowanych metod nauczania, gdzie na pożądany efekt może mieć wpływ wiele czynników, np. postawy studentów, ogólna opinia studentów i odczucia dotyczące metody. Celem badaczy było zrozumienie i ocena czynników występujących w realizowanym projekcie. Analizowane czynniki i schematy zachowań mogą stanowić dobry punkt wyjścia dla nauczycieli w planowaniu projektów. W celu zrozumienia reakcji studentów badacze wykorzystali Q-metodologię identyfikacji różnych grup behawioralnych uczestników na podstawie ich prawdziwych opinii. W prezentowanych badaniach naukowcy analizują odpowiedzi 26 studentów. W rezultacie zaobserwowano 6 przykładów zachowań, z którymi nauczyciele mogą spotkać się w trakcie realizacji nauczania opartego na projekcie. Przedstawiona klasyfikacja jest zgodna z innymi, wcześniej opisanymi rodzajami zachowań studentów, np. postawy „przyjemnych niespodzianek” i ,rozczarowujących niespodzianek”. Jednak pojawiły się inne, dodatkowe rodzaje typów zachowań, np. studenci zorientowani i koncentrujący się na wiedzy teoretycznej, studenci z bardzo silną potrzebą przywództwa i studenci potrzebujący kilku systemów oceny. Przedstawione wyniki mogą zapewnić nauczycielom szerszy pogląd na przygotowywanie i przewidywanie przebiegu planowanych projektów.
\end{abstract}

Słowa kluczowe: uczenie się oparte na projekcie, Q-metodologia, opinia studentów 